NBER WORKING PAPER SERIES

\title{
THE VALUE OF INFORMATION IN INTERNATIONAL TRADE: GAINS TO OUTSOURCING THROUGH HONG KONG
}

\author{
Robert C. Feenstra \\ Gordon H. Hanson \\ Songhua Lin \\ Working Paper 9328 \\ http://www.nber.org/papers/w9328 \\ NATIONAL BUREAU OF ECONOMIC RESEARCH \\ 1050 Massachusetts Avenue \\ Cambridge, MA 02138 \\ November 2002
}

The views expressed herein are those of the authors and not necessarily those of the National Bureau of Economic Research.

(C) 2002 by Robert C. Feenstra, Gordon H. Hanson, and Songhua Lin. All rights reserved. Short sections of text, not to exceed two paragraphs, may be quoted without explicit permission provided that full credit, including (C) notice, is given to the source. 
The Value of Information in International Trade: Gains to Outsourcing through Hong Kong Robert C. Feenstra, Gordon H. Hanson, and Songhua Lin

NBER Working Paper No. 9328

November 2002

JEL No. F1, D8

\section{$\underline{\text { ABSTRACT }}$}

In this paper, we estimate the benefits to countries that purchase goods from China of having access to intermediary services provided by Hong Kong. Traders in Hong Kong supply information on markets and producers in China, which provides welfare gains to foreign firms using these services. During the 1990s, Hong Kong intermediated about half of the goods that China exported to the rest of the world. Our results suggests that gains to intermediary services provided by Hong Kong equal 16\% of the value of goods that China exports to other countries through Hong Kong, and range between 10\% and $21 \%$ of this export value for various manufacturing goods and across different years.

$\begin{array}{lll}\text { Robert C. Feenstra } & \text { Gordon H. Hanson } & \text { Songhua Lin } \\ \text { Department of Economics } & \text { IR/PS } & \text { Department of Economics } \\ \text { University of California } & \text { University of California, San Diego } & \text { Denison University } \\ \text { Davis, CA 95616 } & \text { 9500 Gilman Drive } & \text { Granville, OH 43023 } \\ \text { and NBER } & \text { La Jolla, CA 92093-0519 } & \text { lins@denison.edu } \\ \text { rcfeenstra@ucdavis.edu } & \text { and NBER } & \\ & \text { gohanson@ucsd.edu }\end{array}$




\section{Introduction}

Among the fastest growing countries of the world, China's entry into global markets during the past two decades has already brought large changes to the pattern of world trade. These changes will no doubt be accelerated by its pending entry into the World Trade Organization. But China's large and growing trade volumes have not been achieved through liberalization and growth alone. To a substantial extent, its trade has been intermediated by the entrepôt economy of Hong Kong. Over the period 1988-1998, an average of 53\% of Chinese exports were re-exported through Hong Kong. ${ }^{1}$ Recent theoretical literature emphasizes the importance of intermediaries in reducing informational barriers to international trade (Casella and Rauch, 2003, Rauch and Casella, 2003, Rauch and Trindade, 2000, Rauch and Watson, 2002, Wan and Weisman, 1999). This is confirmed by empirical studies, such as Gould (1994), Head and Ries (1998), and Rauch and Trindade (2002), who find that bilateral trade volumes are higher between countries that share large immigration flows and/or ethnic populations.

Presumably, these networks serve as conduits of information about trading opportunities.

Hong Kong traders engage in a range of activities that benefit their clients. Large trading houses such as Li and Fung identify firms on the mainland that can engage in "outward processing," whereby inputs are imported into China duty-free and processed there, with the final outputs re-exported through Hong Kong (Sung, 1991). ${ }^{2}$ The markups on Hong Kong reexports of Chinese goods averaged 24\% over 1988-96 (Hanson and Feenstra, 2000). For Hong

\footnotetext{
1 Re-exporting means that the goods did not receive "substantial transformation" en-route, but did benefit from sorting, packaging, or the application of service activities such as marketing or transport. Goods that are simply shipped through Hong Kong, without being removed from their carriers, are not counted among re-exports.

2 In addition, firms in Hong Kong broker inflows of foreign direct investment and international loans to China, and advise foreign firms doing business in China (Sung, 1991). Naughton (1999) suggests Hong Kong firms engage in "property rights arbitrage": they use their specific knowledge of business conditions in China and the security of property rights in Hong Kong to broker deals with agents who want access to China's market but are wary about its insecure property rights.
} 
Kong overall, Young (1999) and Enright et al (1997) estimate that trading services accounted for about $20 \%$ of Hong Kong GDP in 1994, whereas manufacturing accounted for only $7 \%$ of GDP in that year. The large value of these trading services suggest that substantial gains accrue to the mainland provinces engaged in processing, as well as the partner countries overseas. For mainland China, Lin (2002) estimates the impact of processing trade on provincial wages. She uses the methodology of Redding and Venables (2000), which involves estimating a gravity equation in the first stage and then using the coefficients from this in a second-stage regression that has wages as the dependent variable. Lin finds that about one-quarter of the wage disparity between coastal provinces can be explained by their access to international markets.

Our goal in this paper is to estimate the benefits to countries that purchase goods from China of having access to intermediary services provided by Hong Kong. Traders in Hong Kong supply information on markets and producers in China, which provides welfare gains to foreign firms using these services. We think of a foreign firm that is considering purchasing an input from China as making a discrete choice over whether to purchase from China directly or via Hong Kong. Data on "outward processing" trade from China is used to measure inputs purchased by foreign firms. ${ }^{3}$ Thinking of the decision problem as a discrete choice over organizational forms - whether to outsource to China directly or through intermediaries in Hong Kong - is consistent with recent theoretical work on trade and organizations, such as Rauch and Trindade (2000) and Grossman and Helpman (2002a,b). ${ }^{4}$

\footnotetext{
${ }^{3}$ Until the early 1990s, China had two regimes for exporters (Naughton, 1996). Those doing outward processing for foreign buyers could import inputs duty free and export abroad directly. Other exporters faced barriers on imported inputs and had to export through state-controlled foreign trade corporations. In 1992, the government began to lift these restrictions, but the customs data from China still maintains the distinction between "processing trade" (which is duty free) and "ordinary trade" (which is subject to duties). We only use data on the former, a substantial portion of which is handled by intermediaries in Hong Kong.

${ }^{4}$ Empirical literature on transactions costs also uses a discrete-choice framework to examine make-or-buy decisions. See Baker and Hubbard (2001) and Whinston (2000) for discussion and references.
} 
In section 2 we describe the discrete choice model, and in section 3 we specify our estimating equations. While we do not observe the actions of individual firms in deciding how to purchase from China, we do observe the country-level flows that are re-exported through Hong Kong. The discrete choice made by each foreign firm purchasing goods from China is aggregated over all such firms in a given country, so that we obtain constant elasticity of substitution (CES) demand functions for exports from China versus Hong Kong, by each province. Thus, we will be using these aggregate trade data to infer the benefits of the discrete choices made by firms. This approach to estimating a discrete choice model is analogous to that used by Berry (1994) for models of product differentiation, except that our functional form (nested CES) will differ from those more used typically (nested or mixed logit).

Our estimating method consists of two stages, described in section 4. First, we estimate gravity equations for Chinese provincial exports to various destination countries. This is done for processed goods that are either exported by China directly or re-exported by Hong Kong. These gravity equations include indicator variables for each source province and destination country pair, which measure the aggregate prices of direct Chinese exports and Hong Kong reexports. In the second stage, we regress each country's purchases of Chinese goods from Hong Kong relative to China on the coefficient of the indicator variables obtained from the gravity equations, which give estimates of price elasticities. We expect that these elasticities should be greater than unity, and we find support for this prediction. In section 5 we use these elasticities to impute the welfare gains from foreign firms being able to purchase Chinese goods through Hong Kong. These gains are about $16 \%$ of the Hong Kong re-export value in the aggregate, and range between $10 \%$ and $21 \%$ of the re-export value for various manufacturing goods (and across different years). In section 6 we conclude. 


\section{Discrete Choice Model}

In our application, we are interested in the decision by a firm to process a good in China. This activity involves producing an intermediate input in a foreign country (e.g., the parts of a shoe) and sending the input to China to be processed into a final good (e.g., assembled into a finished shoe). We present a model of the firm's input sourcing decision and then use this framework to derive aggregate Chinese exports of processed goods, either direct from China or through traders in Hong Kong, to firms in foreign countries. In the next section, we use these results to specify estimating equations for Chinese exports.

We examine the decision of a firm from country $m$ to use China as a partner to acquire a good. We recognize that there are a range of possible suppliers in China, which differ according to their quality and complementarity with the purchasing firm. Previous work (McLaren, 2000; Rauch and Trindade, 2000; Grossman and Helpman, 2002a,b) models this sort of decision using an "idea varieties" approach in which there is product differentiation around a unit-circle. We instead exploit two other equivalent approaches to modeling product differentiation: (i) obtaining "random utility" from various product varieties, and (ii) using a representative agent who purchases all varieties. ${ }^{5}$ We start with the first approach as applied to a purchasing firm, where the random errors measure transaction costs that differ across suppliers. We then show how to aggregate over input sourcing decisions by individual firms in a given country, to obtain a representative firm that chooses over two organizational modes: whether to purchase inputs from China directly or use an intermediary in Hong Kong.

The decision tree for a firm in country $m$ is shown in Figure 1. Firms can either have an input processed in China or have it processed elsewhere. This decision occurs at the first level,

\footnotetext{
5 The equivalence between the ideal-variety and representative consumer approach in international trade models was described most fully by Helpman and Krugman (1985). The equivalence between all three approaches in the consumer context was demonstrated by Anderson, de Palma and Thisse (1992).
} 
where $\mathrm{h}=1$ refers to sending inputs to China for further processing, and $\mathrm{h}=2$ refers to sending inputs elsewhere to be processed. This first choice is implicit in our analysis and not one we examine empirically. We reference this choice here to acknowledge that there are previous decision stages that we do not analyze. At the next level, the firm must decide whether to use intermediaries in Hong Kong ( $\mathrm{i}=1)$, or purchase inputs from China directly ( $\mathrm{i}=2)$. At the final level, the firms (or its intermediaries in Hong Kong) must decide from which province $\mathrm{j} \in \mathrm{J}_{\mathrm{im}}$ in China to purchase the good. The set of supplying provinces $\mathrm{J}_{\mathrm{im}}$ depends on whether or not Hong Kong is used as an intermediary and on the destination country m. As illustrated in Figure 1, this problem involves three levels of nesting. Since we focus on the second and third levels, we suppress subscript $\mathrm{h}$ in what follows.

Suppose that firms in country $m$ commit to spend the amount $C_{m}$ to produce an input, including material purchases and any additional labor needed. We will suppose that these costs are given by a Cobb-Douglas function of the prices $\mathrm{p}_{\mathrm{ijm}}$ paid in Chinese province $\mathrm{j}$, and the prices of other inputs $\mathrm{q}_{\mathrm{im}}$ paid in the home country:

$$
\mathrm{C}_{\mathrm{m}}=\mathrm{y}_{\mathrm{m}}\left(\mathrm{p}_{\mathrm{ijm}}^{\alpha_{\mathrm{i}}} \mathrm{q}_{\mathrm{im}}^{1-\alpha_{\mathrm{i}}}\right), \quad \mathrm{j} \in \mathrm{J}_{\mathrm{im}},
$$

where $y_{m}$ is the production of the finished input. For the outward-processing trade, $q_{\text {im }}$ denotes the cost of the raw materials sent from home and $\mathrm{p}_{\mathrm{ijm}}$ denotes production wages in Chinese province $\mathrm{j} \in \mathrm{J}_{\mathrm{im}}$. The firm may choose to use Hong Kong as an intermediary ( $\mathrm{i}=1$ ) or buy directly from China $(\mathrm{i}=2)$. Note that the cost share of the inputs purchased in China, $\alpha_{i}$, depends on whether Hong Kong is used as an intermediary or not. 
The output $\mathrm{y}_{\mathrm{m}}$ shown in (1) is the expected value of production, which differs from the actual quantity of production $y_{\mathrm{ijm}}$ due to a random error:

$$
\ln \mathrm{y}_{\mathrm{ijm}}=\ln \mathrm{y}_{\mathrm{m}}+\varepsilon_{\mathrm{ijm}},
$$

where $\varepsilon_{\mathrm{ijm}}$ reflects transaction costs arising from outsourcing to a Chinese or Hong Kong partner. The term $\varepsilon_{\mathrm{ijm}}$ in (3) is a random component of production that is observable ex ante to firms. That is, each firm in country $m$ receives a different draw from the distribution for $\varepsilon_{\mathrm{m}}$, and makes its optimizing decisions based on this draw. Let us normalize the price of home labor or materials at unity, $\mathrm{q}_{\mathrm{im}} \equiv 1$. Then solving for expected production $\mathrm{y}_{\mathrm{m}}$ from (1), and substituting this into (2) gives:

$$
\ln y_{i j m}=\ln C_{m}-\alpha_{i} \ln p_{i j m}+\varepsilon_{i j m}, \quad j \in J_{i m} .
$$

In (3), there are two potential advantages to purchasing inputs through Hong Kong rather than from China directly. First, the quality of production for inputs purchased through Hong Kong may be higher, implying a lower effective cost of production, $\mathrm{p}_{1 \mathrm{jm}}$. This might occur if Hong Kong traders have better information about the quality of producers in China than do foreign firms. Second, transaction costs could differ for purchases through Hong Kong. If foreign firms have limited experience in dealing directly with Chinese suppliers or with importing and exporting goods in the country, they might perceive these transaction costs as high relative to those from purchasing through Hong Kong, so that the Hong Kong price $\mathrm{p}_{1 \mathrm{jm}}$ is again low. 
The firm will choose the mode of purchase $i=1,2$ and supplier province $j \in \mathrm{J}_{\mathrm{im}}$ to maximize its production given costs of $\mathrm{C}_{\mathrm{m}}$. The probability that each firm will choose mode $\mathrm{i}$ and province $\mathrm{j}$ is:

$$
\begin{aligned}
\operatorname{Prob}_{i j m} & =\operatorname{Prob}\left[\ln y_{i j m} \geq \ln y_{i^{\prime} j^{\prime} m}, \text { for all } i, i^{\prime}=1,2 ; j \in J_{i m}, j^{\prime} \in J_{i^{\prime} m}\right] \\
& =\operatorname{Prob}\left[-\alpha_{i} \ln p_{i j m}+\varepsilon_{i j m} \geq-\alpha_{i} \ln p_{i^{\prime} j^{\prime} m}+\varepsilon_{i^{\prime} j^{\prime} m}, \text { for all } i, i^{\prime}, j, j^{\prime}\right] \\
& =\operatorname{Prob}\left[\varepsilon_{i j m}-\varepsilon_{i^{\prime} j^{\prime} m} \geq \alpha_{i}\left(\ln p_{i j m}-\ln p_{i^{\prime} j^{\prime} m}\right), \quad \text { for all } i, i^{\prime}, j, j^{\prime}\right]
\end{aligned}
$$

We can think of (4) as the probability that a firm in country m chooses alternative (i,j), or equivalently, as the expected fraction of the firms in country $m$ choosing that alternative. If alternative $(i, j)$ is chosen, then the quantity purchased from province $\mathrm{j}$ is determined from the Cobb-Douglas cost function in (1), using Shepard's Lemma:

$$
\mathrm{x}_{\mathrm{ijm}}=\frac{\partial \mathrm{C}_{\mathrm{m}}}{\partial \mathrm{p}_{\mathrm{ijm}}}=\frac{\alpha_{\mathrm{i}} \mathrm{C}_{\mathrm{m}}}{\mathrm{p}_{\mathrm{ijm}}}
$$

It follows that expected exports from a representative firm in province $\mathrm{j}$ to country $\mathrm{m}$ are: ${ }^{6}$

$$
\mathrm{X}_{\mathrm{ijm}}=\mathrm{x}_{\mathrm{ijm}} \operatorname{Prob}_{\mathrm{ijm}} .
$$

In general, computing the choice probabilities from (4) can be difficult since it requires integration over various subsets of the domain of the random terms $\varepsilon_{\mathrm{m}}$. However, McFadden $(1978,1981)$ shows that as long as $\varepsilon_{\mathrm{m}}$ has a generalized extreme value distribution, the discrete choice problem for the agents can be aggregated to obtain market-level demand quite easily. The most common application of McFadden's theorem is to a consumer setting in which the good in

\footnotetext{
6 We normalize the population of firms in each province at unity, so that (6) is also total exports from province $\mathrm{j}$ to country $\mathrm{m}$, using mode of outsourcing $\mathrm{i}$.
} 
question is purchased in quantity 0 or 1 . In that case, if the random errors in utility are distributed as iid extreme value, then the solution for demand is the familiar logit formulation. If instead the random errors in utility were distributed as extreme value but correlated within some groups, then the solution for demand is the nested logit form.

Our formulation of the firm's problem in (3) and (4) of maximizing production given costs is analogous to the consumer problem of maximizing utility given income. It is more general than the typical discrete choice problem in that we are also allowing the firm to make a continuous choice of the inputs purchased in China (and at home). This falls into the category of so-called "continuous/discrete" models (see Train, 1986). Our formulation of the problem is simplified, however, because there is no uncertainty over the quantity of purchases in (5): the random term in production affects only the choice of supplier in (4). ${ }^{7}$ It turns out that in this setting, the aggregation results of McFadden (1978, 1981) still apply, as we now describe.

Suppose that the random term in (3) is distributed as extreme value but correlated within and across the modes of outsourcing. The distribution function for these errors is,

$$
F\left(\varepsilon_{m}\right)=\exp \left(\sum_{i=1}^{2}\left[\sum_{j \in J_{i m}}-e^{-\varepsilon_{i j m} /\left(1-\rho_{i}\right)} \frac{\left(1-\rho_{\mathrm{i}}\right)}{\left(1-\rho_{0}\right)}\right)^{\left(1-\rho_{0}\right)},\right.
$$

where $\rho_{\mathrm{i}}$ measures the correlation between random terms $\varepsilon_{\mathrm{ijm}}$ within each mode of outsourcing $\mathrm{i}=1,2$, while $\rho_{0}$ measures the correlation of errors across modes. ${ }^{8}$ An implication of the discrete

7 In contrast, Dubin and McFadden (1984) consider an application where there is uncertainty in both the discrete choice of the product and the continuous amount to consume.

8 This distribution function is used by McFadden (1981). Johnson and Kotz (1972) report that with $\rho_{0}=0$, the parameters $\left(1-\rho_{\mathrm{i}}\right)$ equal $\sqrt{1-\operatorname{corr}\left(\varepsilon_{\mathrm{ijm}}, \varepsilon_{\mathrm{ikm}}\right)}$, for $\mathrm{j}, \mathrm{k} \in \mathrm{J}_{\mathrm{im}}$ and $\mathrm{j} \neq \mathrm{k}$. 
choice literature is that the correlation should satisfy $0 \leq \rho_{0} \leq \rho_{i}<1$, meaning that the errors are more highly correlated across provinces within a mode of outsourcing than across outsourcing modes. That is, the uncertainty in transaction costs that a U.S. firm faces when securing a supplier in Yunan versus Shangxi province is more highly correlated than that between the U.S. firm and a Hong Kong intermediary when securing a supplier in the same province.

With the error structure in $(7)$, let $\mathrm{Y}_{\mathrm{m}} \equiv \exp \left[\mathrm{E}\left(\ln \mathrm{y}_{\mathrm{m}}\right)\right]$ denote the expected value of production for a firm in country $\mathrm{m}$ that has spent $\mathrm{C}_{\mathrm{m}}$ on outsourcing. Then it can be shown that expected production (up to a constant) takes on the nested CES form: ${ }^{9}$

$$
Y_{m}=C_{m}\left[\sum_{i=1}^{2}\left(\sum_{j \in J_{i m}} p_{i j m}^{-\alpha_{i} /\left(1-\rho_{i}\right)}\right) \frac{\left(1-\rho_{i}\right)}{\left(1-\rho_{0}\right)}\right]^{\left(1-\rho_{0}\right)}
$$

This formulation can be thought of as an "indirect production function" of the firm, giving expected production $Y_{m}$ conditional on costs $C_{m}$ and input prices. Inverting (8), we obtain the cost function for the representative firm in country m outsourcing to China,

$$
\mathrm{C}_{\mathrm{m}}=\mathrm{Y}_{\mathrm{m}}\left[\sum_{\mathrm{i}=1}^{2}\left(\sum_{\mathrm{j} \in \mathrm{J}_{\mathrm{im}}} \mathrm{p}_{\mathrm{ijm}}^{-\alpha_{\mathrm{i}} /\left(1-\rho_{\mathrm{i}}\right)}\right) \frac{\left(1-\rho_{\mathrm{i}}\right)}{\left(1-\rho_{0}\right)}\right]^{\left(\rho_{0}-1\right)}
$$

We are now in a position to derive exports by suppliers in Chinese provinces to foreign countries, which will form the basis for the estimating equations. Applying Shepard's Lemma to (9), we can compute expected exports from province $\mathrm{j}$ to country $\mathrm{m}$, denoted by $\mathrm{X}_{\mathrm{ijm}}$ as in (6):

9 A principal result of Anderson, de Palma and Thisse $(1989,1992)$ is that the CES indirect utility function is obtained from a discrete choice model using Cobb-Douglas utility with extreme value errors. This is also shown in Feenstra (2003, Appendix B), though the functions in (7) and (8) are somewhat more general than considered there. 


$$
\mathrm{X}_{\mathrm{ijm}}=\frac{\partial \mathrm{C}_{\mathrm{m}}}{\partial \mathrm{p}_{\mathrm{ijm}}}=\left(\frac{\alpha_{\mathrm{i}} \mathrm{C}_{\mathrm{m}}}{\mathrm{p}_{\mathrm{ijm}}}\right) \frac{\mathrm{p}_{\mathrm{ijm}}^{-\alpha_{\mathrm{i}} /\left(1-\rho_{\mathrm{i}}\right)}}{\mathrm{I}_{\mathrm{im}}} \frac{\mathrm{I}_{\mathrm{im}}^{\left[\left(1-\rho_{\mathrm{i}}\right) /\left(1-\rho_{0}\right)\right]}}{\left[\sum_{\mathrm{h}=1}^{2} \mathrm{I}_{\mathrm{hm}}^{\left(1-\rho_{\mathrm{i}}\right) /\left(1-\rho_{0}\right)}\right]},
$$

where the term $\mathrm{I}_{\mathrm{im}} \equiv \sum_{\mathrm{j} \in \mathrm{J}_{\mathrm{im}}} \mathrm{p}_{\mathrm{ijm}}^{-\alpha_{\mathrm{i}} /\left(1-\rho_{\mathrm{i}}\right)}$ appearing in (10) is an "inclusive value". This term is closely related to the price index for Hong Kong re-exports $(i=1)$ or direct Chinese exports ( $\mathrm{i}=2$ ), which we define as:

$$
\mathrm{P}_{\mathrm{im}} \equiv\left[\sum_{\mathrm{j} \in \mathrm{J}_{\mathrm{im}}} \mathrm{p}_{\mathrm{ijm}}^{-\alpha_{\mathrm{i}} /\left(1-\rho_{\mathrm{i}}\right)}\right]^{-\left(1-\rho_{\mathrm{i}}\right) / \alpha_{\mathrm{i}}}=\mathrm{I}_{\mathrm{im}}^{-\left(1-\rho_{\mathrm{i}}\right) / \alpha_{\mathrm{i}}}, \quad \mathrm{i}=1,2
$$

Comparing (10) with (5) and (6), we see that the final two ratios on the right of (10) equal Prob $_{\mathrm{ijm}}$, the probability that province $\mathrm{j}$ and mode $\mathrm{i}$ are chosen by a firm in country $\mathrm{m} .{ }^{10}$ These two ratios would also appear in a nested logit system, so that the new feature of exports in (10) is the term $\left(\alpha_{\mathrm{i}} \mathrm{C}_{\mathrm{m}} / \mathrm{p}_{\mathrm{ijm}}\right)$, which reflects the continuous quantity choice of inputs.

We can use demand in (10) to solve for the elasticity of substitution between products. For two supplying provinces $\mathrm{j}, \mathrm{k} \in \mathrm{J}_{\mathrm{im}}$, we obtain the relative demand from country $\mathrm{m}$,

$$
\frac{X_{i j m}}{X_{i k m}}=\left(\frac{p_{j}}{p_{k}}\right)^{-\left[\alpha_{i} /\left(1-\rho_{i}\right)\right]-1}, j, k \in J_{i m}
$$

Thus, the elasticity of substitution between two provincial suppliers, using either Hong Kong as an intermediary $(i=1)$ or purchasing directly from China $(i=2)$, is $1+\left[\alpha_{i} /\left(1-\rho_{i}\right)\right]>1$.

\footnotetext{
${ }^{10}$ The ratio $\left[\mathrm{p}_{\mathrm{ijm}}^{-\alpha_{\mathrm{i}} /\left(1-\rho_{\mathrm{i}}\right)} / \mathrm{I}_{\mathrm{im}}\right]$ is the probability that province $\mathrm{j}$ is chosen given that outsourcing mode $\mathrm{i}$ is used, and the ratio $\mathrm{I}_{\mathrm{im}}^{\left(1-\rho_{\mathrm{i}}\right) /\left(1-\rho_{0}\right)} /\left[\sum_{\mathrm{h}=1}^{2} \mathrm{I}_{\mathrm{hm}}^{\left(1-\rho_{\mathrm{i}}\right) /\left(1-\rho_{0}\right)}\right]$ is the probability that the mode of outsourcing $\mathrm{i}=1,2$ is chosen.
} 
In addition, we can use (10) to compute the ratio of country m expenditure on all products from Hong Kong versus all products imported directly from China. Define the total value of exports to country $m$ in each mode as,

$$
\mathrm{E}_{\mathrm{im}}=\sum_{\mathrm{j} \in \mathrm{J}_{\mathrm{im}}} \mathrm{p}_{\mathrm{ijm}} \mathrm{X}_{\mathrm{ijm}}, \quad \mathrm{i}=1,2 .
$$

Then from (10) we have that Hong Kong relative to China exports to country m are:

$$
\frac{E_{1 m}}{E_{2 m}}=\frac{I_{1 m}^{\left(1-\rho_{1}\right) /\left(1-\rho_{0}\right)}}{I_{2 m}^{\left(1-\rho_{2}\right) /\left(1-\rho_{0}\right)}} .
$$

This can be re-written in real terms using the price indexes from (11):

$$
\frac{E_{1 m} / P_{1 m}}{E_{2 m} / P_{2 m}}=\frac{P_{1 m}^{-\left[\alpha_{1} /\left(1-\rho_{0}\right)\right]-1}}{P_{2 m}^{-\left[\alpha_{2} /\left(1-\rho_{0}\right)\right]-1}}
$$

The left-side of (13) is ratio of purchases from Hong Kong versus purchases from China directly, deflated by their price indexes, and so can be interpreted as a ratio of real exports. We see that this depends on the ratio of price indexes for the two modes of outsourcing, and the elasticities with respect to each price index are $1+\left[\alpha_{\mathrm{i}} /\left(1-\rho_{0}\right)\right]>1$. With $0 \leq \rho_{0} \leq \rho_{\mathrm{i}}<1$, these higher-level elasticities are less than or equal to the lower-level elasticities of substitution, $1+\left[\alpha_{\mathrm{i}} /\left(1-\rho_{0}\right)\right] \leq 1+\left[\alpha_{\mathrm{i}} /\left(1-\rho_{\mathrm{i}}\right)\right]$.

In (10) we have an expression for exports of processed goods from a Chinese province, under either mode of outsourcing (direct from China or through Hong Kong), to purchasing country $\mathrm{m}$, and in (13) we have an expression for total exports to purchasing country $\mathrm{m}$ by the 
direct China outsourcing mode relative to total exports to country $m$ by the Hong Kong outsourcing mode. These two equations are the basis for our empirical work.

\section{Estimating Equations}

Equations (10) and (13) contain variables that are difficult to measure empirically. With some modification, we can convert these expressions into a specification that we can estimate with available data. Rather than use the quantity of exports from (10) in our empirical work, we convert it to a value $E_{i j m}=p_{i j m} X_{i j m}$, which is exports from province $\mathrm{j}$ to country $\mathrm{m}$ using the mode of outsourcing $i=1,2$. The total value of exports to country $\mathrm{m}$ in each mode is as in (12). Then the provincial and total exports are computed from (10) as:

$$
\mathrm{E}_{\mathrm{ijm}}=\mathrm{E}_{\mathrm{im}}\left(\frac{\mathrm{p}_{\mathrm{ijm}}^{-\alpha_{\mathrm{i}} /\left(1-\rho_{\mathrm{i}}\right)}}{\mathrm{I}_{\mathrm{im}}}\right),
$$

and,

$$
\mathrm{E}_{\mathrm{im}}=\alpha_{\mathrm{i}} \mathrm{C}_{\mathrm{m}}\left(\frac{\mathrm{I}_{\mathrm{im}}^{\left(1-\rho_{\mathrm{i}}\right) /\left(1-\rho_{0}\right)}}{\sum_{\mathrm{h}=1}^{2} \mathrm{I}_{\mathrm{hm}}^{\left(1-\rho_{\mathrm{i}}\right) /\left(1-\rho_{0}\right)}}\right)
$$

We will let the c.i.f. prices $\mathrm{p}_{\mathrm{ijm}}$ from province $\mathrm{j}$ in China differ according to destination country $\mathrm{m}$, due to transportation costs. These are modeled as a simple function of distance:

$$
\mathrm{p}_{\mathrm{ijm}}=\mathrm{p}_{\mathrm{ij}}\left(1+\mathrm{d}_{\mathrm{ijm}}\right)^{\beta} \text {, }
$$

where $d_{i j m}$ is the distance from province $\mathrm{j}$ to country $\mathrm{m}$, and $\mathrm{p}_{\mathrm{ij}}$ is the f.o.b. price in province $\mathrm{j}$ net of any transport costs. Substituting these prices into (14) and (15), we can write exports as: 


$$
\ln \left(E_{i j m} / E_{i m}\right)=-\left[\alpha_{i} /\left(1-\rho_{i}\right)\right] \ln p_{i j}-\ln I_{i m}-\left[\alpha_{i} \beta /\left(1-\rho_{i}\right)\right] \ln \left(1+d_{i j m}\right)
$$

and,

$$
\ln \left(\frac{E_{1 m}}{E_{2 m}}\right)=\ln \left(\frac{\alpha_{1}}{\alpha_{2}}\right)+\left(\frac{1-\rho_{1}}{1-\rho_{0}}\right) \ln I_{1 m}-\left(\frac{1-\rho_{2}}{1-\rho_{0}}\right) \ln I_{2 m}
$$

Equation (17) gives exports from province $\mathrm{j}$ to country m relative to total Chinese exports to country m, either via Hong Kong ( $\mathrm{i}=1$ ) or directly (i=2). These relative exports depend on the f.o.b. price in province $\mathrm{j}, \ln \mathrm{p}_{\mathrm{ij}}$, which we do not observe. But in a dataset with observations on provincial exports to many purchasing countries, we can estimate this first variable on the right of (17) as the coefficient on indicator variable for province $j, \delta_{i j} \equiv-\left[\alpha_{i} /\left(\rho_{i}-1\right)\right] \ln p_{i j}$, depending on the mode of outsourcing. The second variable on the right of (17) is the inclusive value for exports of mode i to country m. Again, with data on exports to purchasing countries from many provinces we can estimate this as the coefficient on a indicator variable for purchasing country $\mathrm{m}, \delta_{\mathrm{im}} \equiv-\ln \mathrm{I}_{\mathrm{im}}$, depending on the mode of outsourcing. Then we re-write (17) to obtain our first regression equation:

$$
\ln \left(E_{i j m} / E_{i m}\right)=\delta_{i j}+\delta_{i m}+\gamma_{i} \ln \left(1+d_{i j m}\right)+\mu_{i j m}, \quad j \in J_{i m}, m=1, \ldots, M
$$

where $\gamma_{i j} \equiv-\left[\alpha_{i} \beta /\left(\rho_{i}-1\right)\right]$. The error term in (19) reflects the fact that the c.i.f. price may differ randomly from the f.o.b. price due to unobserved trade costs.

The second regression equation is (18), which includes as data a constant term and the indicator variables $\delta_{\mathrm{im}} \equiv-\ln \mathrm{I}_{\mathrm{im}}, \mathrm{i}=1,2$. Of course, the estimated value of these from the first equation must be used, so that (18) is re-written as: 


$$
\ln \left(\frac{E_{1 m}}{E_{2 m}}\right)=\alpha_{0}-\left(\frac{1-\rho_{1}}{1-\rho_{0}}\right) \hat{\delta}_{1 m}+\left(\frac{1-\rho_{1}}{1-\rho_{0}}\right) \hat{\delta}_{2 m}+\mu_{m}, \quad m=1, \ldots, M
$$

where the signs of the coefficients on the right have changed from (18) due to the substitution $\delta_{\text {im }} \equiv-\ln \mathrm{I}_{\text {im }}, \mathrm{i}=1,2 .{ }^{11}$

In the first stage of estimation, we shall estimate (19) while pooling over Chinese provinces $\mathrm{j}=1, \ldots, \mathrm{J}_{\mathrm{im}}$ and destination countries $\mathrm{m}=1, \ldots, \mathrm{M}$. Separate regressions are estimated depending on whether the Chinese exports go through Hong Kong or not $(\mathrm{i}=1,2)$, and also for each year of data. The estimates of $\delta_{\text {im }} \equiv-\ln \mathrm{I}_{\mathrm{im}}, \mathrm{i}=1,2$, are obtained as the coefficients of indicator variables for each source-province and destination-country pair in (19), leaving distance as the remaining independent variable. In the second stage, these inclusive values are used in (20) to estimate the relative expenditure on exports from Hong Kong versus directly from China, using the data $\mathrm{m}=1, \ldots, \mathrm{M}$ over destination countries. We will also pool data over multiple years to estimate (20), on the assumption that the parameters $\rho_{\mathrm{i}}$ and $\rho_{0}$ are constant over time.

We can compare (19) with a conventional estimation of the gravity equation, under which exports are regressed on country GDPs and the distance between them. Anderson and Van Wincoop (2001) have correctly criticized this conventional approach since it fails to take account of the price indexes that should appear in the equation. They show how to solve implicitly for the price index using observed trade data, and build this into their estimation. The inclusive values that we have used are very similar to their price indexes: in logs the price indexes in (11) are $\ln P_{i m}=-\left[\left(1-\rho_{i}\right) / \alpha_{i}\right] \ln I_{i m}=\left[\left(1-\rho_{i}\right) / \alpha_{i}\right] \delta_{\text {im }}$, so the indicator variables $\delta_{\text {im }}$ are directly proportional to the prices indexes.

11 Since the regressors in (20) are estimated, we use bootstrapped standard errors to compute the t-statistics. 
By including the indicator variables $\delta_{\text {im }}$ in equations (19) and (20),we are effectively including the price indexes, consistent with the critique of Anderson and van Wincoop (2001). This approach is similar to Redding and Venables (2000), who show how a correct estimation of the gravity equation can be obtained by using indicator variables for source and destination countries; in comparison, we are including indicator variables for each source province and each destination country. After estimating these indicator variables in a first stage, Redding and Venables proceed by specifying a second-stage regression that uses these indicator variables to estimate wages in exporting countries. In this formulation, trade benefits exporters by raising wages. In contrast, we shall use the estimates from (20) to impute benefits to importers from having Hong Kong available as an intermediary in outsourcing to China. The details of this welfare calculation will be discussed after presenting estimates of (19) and (20).

\section{Data and Estimation}

Data on direct trade between Chinese provinces and destination countries is obtained from the Customs General Administration of the People's Republic of China, which provides the value and quantity of exports and imports under the ordinary and processing trade regime by province and year for 1988 to 1998. To compile indirect exports of Chinese goods that are sent to Hong Kong and then re-exported, we use Hong Kong imports, exports, and re-exports from the Hong Kong Census and Statistical Office for 1988 to 1998.

We measure distance between Chinese provinces and the rest of the world in two different ways: arc distance, ${ }^{12}$ which is the minimum-length arc that connects each Chinese province to a destination country, and "internal-external" distance, which assumes that goods

\footnotetext{
${ }^{12}$ We obtain each location's latitude and longitude from http://www.mapblast.com/myblast/index.mb , and http://www.nau.edu/ cvm/latlongdist.html provides the distance calculation.
} 
from an interior province must pass through a transportation hub in a coastal province (internal distance), and then be delivered to the rest of the world (external distance). Internal distance is in terms of rail distance, obtained from Chinese railroad timetables. External distance is the arc distance between a Chinese port and the destination country.

Table 1 shows total China exports, China outward processing exports, and Hong Kong re-exports of Chinese goods for 1988-1998. Total China exports (direct trade plus re-exports) have risen dramatically over time. Outward processing and shipments through Hong Kong are a substantial part of this total. The outward processing share of China's total exports in column (6) increases from $32 \%$ in 1988 to $55 \%$ by 1998 . The re-export share of China's total exports in column (2) increases from $43 \%$ in 1988 to $61 \%$ in 1993 and then declines to $45 \%$ by 1998 . The decline in the later period may be due in part to increases in exports by Chinese regions distant from Hong Kong (Sung, 1997). The re-export share of Chinese outward processing exports shown in column (3) also rises and then falls, from $67 \%$ in 1988 to $83 \%$ in 1993 and then down to $61 \%$ by 1998 . Columns (4)-(6) show that the outward processing share of direct Chinese exports is smaller than for Hong Kong re-exports, though both have been rising over time.

Table 2 shows the distribution of total Chinese exports and Hong Kong re-exports of Chinese goods across one-digit SITC (Standard Industrial Trade Classification) industries. About $43 \%$ of total exports are in miscellaneous manufactured articles (SITC 8), whose major sub-sectors are apparel, footwear and toys. Machinery and transport equipment (SITC 7) and manufactured goods classified by material (SITC 6), which include leather, metal, paper, rubber, textile and wood products, are two additional important sources of exports, each accounting for $17 \%$ of shipments. SITC 7 and 8 are the two industries in which re-exports account for the 
largest fraction of total exports, with re-export shares of 70\%. These are also the two industries in which outward-processed goods dominate China's shipments to Hong Kong.

Table 3 shows the distribution of direct exports and Hong Kong re-exports across regions and the average share of re-exports in total exports by region. For both direct exports and reexports, the major destinations are the relatively large markets of North America, Western Europe, and East Asia. The regions for which re-exports account for most trade include the relatively rich and distant regions of North America (71\%) and Western Europe (62\%), the relatively rich and near region of Oceania (61\%), and the relatively poor and distant regions of Latin America (65\%) and Africa (50\%). Evidently, the benefits of using Hong Kong as an intermediary are less important for other nearby countries in Asia, and Eastern Europe.

\subsection{Gravity Equation}

In the first stage regression, we estimate the gravity equation in (19). We show results for both measures of distance. Table 4 reports OLS coefficient estimates for 1995. Estimates for other years are very similar. The dependent variable is direct Chinese exports or indirect Hong Kong re-exports from Chinese provinces to destination countries. All exports are of goods related to outward processing. The independent variables are the log of arc distance or the log of internal distance plus the log of external distance, as well as indicator variables for the destination country and the Chinese province. For direct exports from China, coefficients on arc distance and internal-external distance are negative and precisely estimated. For Hong Kong reexports, coefficients on internal-external distance are negative and precisely estimated, but the coefficient on arc distance has a positive sign. We constructed arc distance for Hong Kong reexports as the sum of the arc distance between the Chinese province and Hong Kong and the arc distance between Hong Kong and rest of the world. We suspect that the arc distance between the 
Chinese province and Hong Kong may be a poor indicator of true transportation cost because of uneven rail, road, and water links within the country. Internal-external distance is likely to be a better measure of this type of transportation costs.

To see whether coefficient estimates vary across industries, Table 5 presents regression results on the gravity equation in 1995 for one-digit SITC industries. We first show results for direct Chinese trade and then for Hong Kong re-exports. In both cases, the distance measure is the internal-external variable. There are more observations for Hong Kong re-exports than for direct China trade, which suggests that Chinese provinces are able to trade with a larger number of countries when firms use traders in Hong Kong as intermediaries. For direct China trade, in most industries internal and external distance are negatively correlated with exports. A few industries, such as beverages and tobacco, have anomalous results.

For Hong Kong re-exports, in most industries internal distance is negative and precisely estimated but external distance is estimated quite imprecisely. It appears that Hong Kong reexports of Chinese goods are only weakly correlated with distance to the destination country. One explanation of this result is that since external distance is the arc distance from Hong Kong to the destination country it may be a noisy measure of transportation cost. A second explanation is that internal distance, the distance from a Chinese port to the exporting province, is the primary concern of purchases in importing countries. Given large costs of transporting goods from China's interior to the coast, firms in destination countries prefer to purchase goods from provinces that have a geographic advantage in delivering the goods to Hong Kong.

\subsection{Hong Kong Re-exports versus Direct Chinese Exports}

In the second-stage regression, equation (20), we use the estimated coefficients on the

destination-country indicator variables, $\hat{\delta}_{\mathrm{im}}, \mathrm{i}=1,2$, obtained from estimation of the first-stage 
gravity equation (using the internal-external distance variable). These coefficients are proportional to the price indexes for either direct purchases from China or indirect purchases through Hong Kong. The dependent variable in (20) is the ratio of Hong Kong re-exports to direct China exports to a given destination country. An increase in the Hong Kong inclusive value (price index) should lower the relative Hong Kong share, while an increase in the direct China inclusive value (price indexes) should raise the relative Hong Kong share. ${ }^{13}$ Therefore, the Hong Kong inclusive value (price index) should enter with a negative sign in (20), and the direct China inclusive value should enter with a positive sign. We run this regression with data pooled over 11 years, all destination countries, and all industries.

Table 6 presents the estimation results for the second-stage regression. The implication of the discrete choice literature that $0 \leq \rho_{0} \leq \rho_{\mathrm{i}}<1$ means that the estimated coefficients on inclusive values (price indexes) should both be less than unity in absolute value. The results are consistent with this restriction under either specification of distance. In addition the signs of the estimated coefficients are all as expected and are all precisely estimated.

Table 7 reports the second-stage estimation results at the one-digit SITC level. The first column of Table 7 indicates that for most industries the Hong Kong inclusive values have the expected negative sign and are precisely estimated. The exceptions are manufacturing goods classified by material, which has the wrong sign, and miscellaneous manufacturing articles, which is imprecisely estimated. ${ }^{14}$ In the second column, the inclusive values for direct Chinese trade have the expected positive sign and are precisely estimated for five industries and are imprecisely estimated for three industries.

13 Recall from (13) that the elasticities of the relative expenditures with respect to each price index is greater than one in absolute value.

14 When the second-stage regression for manufacturing goods classified by material is run using the inclusive values obtained from the first-stage using arc distance, the second-stage results are stronger, as indicated in the notes to Table 7. Those results are used for the calculations in Table 9. 


\section{Welfare Benefits from China's Trade with Hong Kong}

We turn now to the question posed at the outset of the paper: what is the welfare gain to a country from being able to purchase Chinese goods through Hong Kong rather than from China directly? Going through Hong Kong gives purchasers access to intermediary services they might not have, otherwise. We utilize the indirect production function in (8) for the representative firm in country $m$. Using the indicator variables $I_{i m} \equiv \sum_{j \in J_{i m}} p_{i j m}^{-\alpha_{i} /\left(1-\rho_{i}\right)}$, we can write this value as,

$$
\mathrm{Y}_{\mathrm{m}}=\mathrm{C}_{\mathrm{m}}\left[\mathrm{I}_{1 \mathrm{~m}}^{\left(1-\rho_{1}\right) /\left(1-\rho_{0}\right)}+\mathrm{I}_{2 \mathrm{~m}}^{\left(1-\rho_{2}\right) /\left(1-\rho_{0}\right)}\right]^{\left(1-\rho_{0}\right)}
$$

The benefits to a purchasing country from having Hong Kong available can be computed as the $\log$ of the ratio of expected production with and without this intermediary, or,

$$
\begin{aligned}
\left(1-\rho_{0}\right) \ln \left[\left(\mathrm{I}_{1 \mathrm{~m}}^{\left(1-\rho_{1}\right) /\left(1-\rho_{0}\right)}+\mathrm{I}_{2 \mathrm{~m}}^{\left(1-\rho_{2}\right) /\left(1-\rho_{0}\right)}\right) / \mathrm{I}_{2 \mathrm{~m}}^{\left(1-\rho_{2}\right) /\left(1-\rho_{0}\right)}\right] \\
=\left(1-\rho_{0}\right) \ln \left[\left(\mathrm{E}_{1 \mathrm{~m}}+\mathrm{E}_{2 \mathrm{~m}}\right) / \mathrm{E}_{2 \mathrm{~m}}\right]
\end{aligned}
$$

where the second line is obtained by making use of Hong Kong re-exports and China exports, $\mathrm{E}_{1 \mathrm{~m}}$ and $\mathrm{E}_{2 \mathrm{~m}}$, as in (15). This welfare expression can be re-written as,

$$
\begin{aligned}
& \left(1-\rho_{0}\right) \ln \left[\left(E_{1 \mathrm{~m}}+E_{2 \mathrm{~m}}\right) / E_{2 \mathrm{~m}}\right]=\left(\rho_{0}-1\right) \ln \left[\mathrm{E}_{2 \mathrm{~m}} /\left(\mathrm{E}_{1 \mathrm{~m}}+\mathrm{E}_{2 \mathrm{~m}}\right)\right] \\
& =\left(\rho_{0}-1\right) \ln \left\{1-\left[\mathrm{E}_{1 \mathrm{~m}} /\left(\mathrm{E}_{1 \mathrm{~m}}+\mathrm{E}_{2 \mathrm{~m}}\right)\right]\right\} \geq\left(1-\rho_{0}\right)\left[\mathrm{E}_{1 \mathrm{~m}} /\left(\mathrm{E}_{1 \mathrm{~m}}+\mathrm{E}_{2 \mathrm{~m}}\right)\right],
\end{aligned}
$$

where the final inequality follows from the concavity of the natural log function.

From (22), a lower-bound to the welfare gain is the share of Hong Kong re-exports in total Chinese trade times the coefficient $\left(1-\rho_{0}\right)$, which is inversely related to the upper-level 
elasticity $1+\left[\alpha_{i} /\left(1-\rho_{0}\right)\right]$. The result that the welfare gain from a "new product" equals its share of expenditure times a term inversely related to the elasticity is obtained for CES functions by Feenstra (1994). The expression in (22) is completely analogous to this CES result, where the "new product" is the Hong Kong intermediaries. The more valuable is the information provided by these traders, the higher will be expenditure on Hong Kong re-exports, and the greater is the welfare gain in (22); conversely, the higher is the elasticity, the lower is the welfare gain. ${ }^{15}$

To compute this gain, however, we need to have an estimate of $\rho_{0}$. Our second-stage estimation in (20) provides us with estimates of the ratios $\left(1-\rho_{1}\right) /\left(1-\rho_{0}\right)$ and $\left(1-\rho_{2}\right) /\left(1-\rho_{0}\right)$. In order to obtain $\rho_{0}$, therefore, we need some independent estimates of $\rho_{1}$ or $\rho_{2}$. To obtain this, we note that from (10) the coefficient $1+\alpha_{1} /\left(1-\rho_{1}\right)$ equals the own-price elasticity of demand for a reexport from any province through Hong Kong. Consider a trader in Hong Kong who buys some good $\mathrm{k}$ in China and then re-exports it. The trader will choose price $\mathrm{p}_{1 \mathrm{k}}$ (where $\mathrm{i}=1$ indicates Hong Kong re-exports k denotes the good) to maximize profits. From the first-order conditions to the trader's profit-maximization problem, we can express the markup of price over marginal cost as inversely related to the price elasticity of demand:

$$
\frac{\mathrm{p}_{1 \mathrm{k}}-\mathrm{c}_{1 \mathrm{k}}}{\mathrm{p}_{1 \mathrm{k}}}=\frac{1}{1+\left[\alpha_{1} /\left(1-\rho_{1}\right)\right]}
$$

where $\mathrm{p}_{1 \mathrm{k}}$ is the f.o.b. price for good $\mathrm{k}$ in Hong Kong, and $\mathrm{c}_{1 \mathrm{k}}$ is the marginal cost to the trader of obtaining good k from China.

15 We prefer using the lower-bound on the right of (22) to the expression in (21), because it can be argued that (22) is robust to having alternative options for outsourcing beyond just Hong Kong and China directly. Recall from Figure 1 that a firm in country $m$ first has the choice over whether to purchase from China (directly or via Hong Kong) or from another country. Even if we take these alternative countries into account, the welfare gain from using Hong Kong is still bounded from below by the share of Hong Kong in total expenditure on outsourcing. 
We calculate the markup on the left of (23) based on the price at which Hong Kong imports disaggregate goods from China, and the price at which it re-exports them, as described in Feenstra, et al $(1998,1999)$. Denoting these markups by $\pi_{1 \mathrm{k}}$, we obtain the simple equation,

$$
\pi_{1 \mathrm{k}}=\frac{1}{1+\left[\alpha_{1} /\left(1-\rho_{1}\right)\right]}+\varepsilon_{1 \mathrm{k}}
$$

where the error term reflects inaccuracies in measuring the markups across goods. Therefore, an estimate of the elasticity of demand for products re-exported through Hong Kong is:

$$
\bar{\pi}_{1}=\frac{1}{1+\left[\hat{\alpha}_{1} /\left(1-\hat{\rho}_{1}\right)\right]},
$$

where we take the mean of the markups over all products. The mean Hong Kong markups for each of the years in our sample is shown in column (1) of Table 8. With these, we calculate the elasticity of demand as $1+\hat{\alpha}_{1} /\left(1-\hat{\rho}_{1}\right)=1 / \bar{\pi}_{1}$.

Next, we obtain an estimate of the cost-share $\alpha_{1}$ by using Chinese trade data on processing trade. Specifically, we compute $\alpha_{1}$ as the difference between Chinese processing exports and processing imports from Hong Kong, divided by the value of processing exports. This calculation reflects the value-added of processing goods in China, relative to their final export value, and the results are shown in column (2) of Table $8 .{ }^{16}$ The value-added in China was about $12 \%$ of exports in 1989 , rising to one-third of export value in 1998 . Using these estimates, the implied value of $\left(1-\hat{\rho}_{1}\right)$ in column $(3)$ is obtained as $\hat{\alpha}_{1} /\left[\left(1 / \bar{\pi}_{1}\right)-1\right]$.

16 We make this calculation for processing goods imported to China from Hong Kong, and then exported back to Hong Kong. A much smaller value of processing goods enter China from other countries, which would provide us with an estimate of $\alpha_{2}$ rather than $\alpha_{1}$. We find that $\alpha_{2}$ is more than twice as high as $\alpha_{1}$ in early years, but similar in recent years. 
Finally, we divide $\left(1-\hat{\rho}_{1}\right)$ by the absolute coefficient on the Hong Kong indicator variable in regression (20), which was 0.28 in Table 6 , to obtain an estimate of $\left(1-\hat{\rho}_{0}\right)$. These values are shown in column (4) of Table 8, and fluctuate between 0.1 and 0.4 . Multiplying these by the Hong Kong share of total processing exports from China, in column (5), we obtain the welfare gains shown in column (6). These gains are between $9 \%$ and $24 \%$ of expenditure on processing exports, averaging $16 \%$ over the sample years. The variation around this average reflects annual fluctuations in the markups charged on Hong Kong re-exports, as well as the value-added in China on processing goods.

In Table 9, we perform the same calculation using the one-digit SITC industries. In several industries, such as food and live animals, beverages and tobacco, and mineral fuels, reexports through Hong Kong are so low that there is little gain to this activity. But for many manufactured goods (SITC 6 and 7), we obtain sizable estimates of the welfare gain: 10\% for the large category of manufactured goods classified by material, and $21 \%$ for machinery and transportation equipment. ${ }^{17}$ Unfortunately, in the category of miscellaneous manufactured articles (SITC 8) we did not obtain a coefficient on the Hong Kong inclusive value of the correct sign, so we cannot make the welfare calculation in this industry. Across all industries, we utilize the aggregate second-stage regression coefficients in Table 6, and again find a welfare gain of $16 \%$, as obtained when we averaged the annual data.

17 In manufactured goods classified by material, we use the absolute coefficient on the Hong Kong indicator variable of 0.23 , reported in the notes to Table 7 . This is obtained using arc distance in the gravity equation. In addition, we use the aggregate cost share $\alpha_{1}=0.23$, which is the average over $1988-1998$ from Table 8 . This cost share cannot be calculated at the industry level from our data. 


\section{Conclusions}

Recent theoretical work in international trade emphasizes the importance of traders: agents who are able to match clients across different countries. Among the largest traders in the world economy are those located in Hong Kong, who intermediate a huge volume of trade for China and other Asian countries. This intermediation surely brings significant gains to their clients, and in this paper we estimate the welfare gains to countries that use Hong Kong to outsource to China. Such outsourcing can be measured by outward processing trade in China.

Our theoretical model allows us to impute price indexes (or "inclusive values") for Hong Kong re-exports versus direct Chinese exports to various destination countries. The demand for each of these two modes of outsourcing is elastic (due to the presence of the other alternative), so an increase in either price should reduce the share of expenditure on those exports. We obtain price elasticities of the anticipated sign for Hong Kong re-exports of processing goods. Using these, the gains are calculated at 16\% of the Hong Kong re-export value of processing goods, and range between $10 \%$ and $21 \%$ of the re-export value for specific manufacturing goods. For example, China's total exports of processing goods (either directly or via Hong Kong) was nearly US\$ 100 billion in 1998. Applying the welfare estimate of $16 \%$, this yields gains of US\$ 16 billion to the purchasing countries. About one-third of these gains would accrue to firms in North America, and another one-quarter to firms in Western Europe. These represent efficiency gains to the firms involved in outsourcing, due to savings in transaction costs that would arise from dealing directly with firms in China. The efficiency gain of $16 \%$ is sizable by any standard, and would be passed onto consumers worldwide in lower prices for goods outsourced through Hong Kong. 


\section{References}

Anderson, James and Eric van Wincoop, 2001, "Gravity with Gravitas: A Solution to the Border Puzzle," NBER working paper no. 8079.

Anderson, Simon P., Andre de Palma, and Jacques-Francois Thisse, 1992, Discrete Choice Theory of Product Differentiation, Cambridge, MA: MIT Press.

Baker, George P. and Thomas N. Hubbard, 2001, "Empirical Strategies in Transaction Cost Economics: Information and the Boundary of the Firm." American Economic Review 91: 184-188.

Casella, Alessandra, and James E. Rauch, 2003, “Anonymous Market and Group Ties in International Trade," Journal of International Economics, forthcoming.

Dubin, Jeffrey A. and Daniel L. McFadden, 1984, “An Econometric Analysis of Residential Electric Appliance Holdings and Consumption," Econometrica, 52(2). March, 345-362.

Enright, Michael J., Edith E. Scott, and David Dodwell. 1997. The Hong Kong Advantage. Hong Kong: Oxford University Press.

Feenstra, Robert C., 2003. Advanced International Trade: Theory and Evidence. Princeton: Princeton University Press.

Feenstra, Robert C, 1994, "New Product Varieties and the Measurement of International Prices," American Economic Review, 84(1), March, 157-177.

Feenstra, Robert, Wen Hai, Wing T. Woo, and Shunli Yao, 1998, “The U.S.-China Bilateral Trade Balance: Its Size and Determinants,” NBER Working Paper no. 6598, June.

Feenstra, Robert, Wen Hai, Wing T. Woo, and Shunli Yao, 1999, "Discrepancies in International Data: An Application to China-Hong Kong Entrepôt Trade," American Economic Review Papers and Proceedings, May.

Gould, David M, 1994, "Immigrant Links to the Home Country: Empirical Implications for U.S. Bilateral Trade Flows.” Review of Economics and Statistics 76: 302-316.

Grossman, Gene M. and Elhanan Helpman, 2002a, "Integration versus Outsourcing in Industry Equilibrium," Quarterly Journal of Economics, 117(1), May, 85-120.

Grossman, Gene M. and Elhanan Helpman, 2002b, “Outsourcing in a Global Economy, "NBER Working Paper No.8728.

Hanson, Gordon H. and Robert C. Feenstra, 2001, "Intermediaries in Entrepôt Trade: Hong Kong Re-Exports of Chinese Goods,” NBER Working Paper no. 8088. 
Head, Keith and John Ries, 1998, "Immigration and Trade Creation: Econometric Evidence from Canada." Journal of International Economics 31(1): 47-62

Helpman, Elhanan and Paul R. Krugman, 1985, Market Structure and Foreign Trade. Cambridge: MIT Press.

Johnson, Norman Lloyd and Samuel Kotz, 1972, Distributions in Statistics: Continuous Multivariate Distributions. New York: Wiley.

Lin, Songhua, 2003, Ph.D. Dissertation, University of California, Davis.

McFadden, Daniel, 1978, "Modeling the Choice of Residential Location," in Anders Karlqvist, L. Lundqvist, F. Snickars, and J. Weibull, eds., Spatial Interaction Theory and Planning Models, Amsterdam: North-Holland, 75-96.

McFadden, Daniel, 1981, “Econometric Models of Probabilistic Choice," in Charles F. Manski and Daniel McFadden, eds., Structural Analysis of Discrete Data with Econometric Applications, Cambridge, MA: MIT Press, 198-272.

Naughton, Barry, 1996, “China's Emergence and Prospects as a Trading Nation,” Brookings Papers on Economic Activity, 2: 1996, pp. 273-343.

Naughton, Barry, 1999, "Between China and the World: Hong Kong's Economy Before and After 1997," in Gary Hamilton, ed., Cosmopolitan Capitalists: Hong Kong and the Chinese Diaspora at the End of the Twentieth Century. Seattle: University of Washington Press.

Rauch, James E. and Alessandra Casella, 2003, “Overcoming Informational Barriers to International Resource Allocation: Prices and Group Ties," Economic Journal, forthcoming.

Rauch, James E. and Vitor Trindade, 2000, "Information and Globalization: Wage CoMovements, Labor Demand Elasticity, and Conventional Trade Liberalization" NBER Working Paper no. 7671.

Rauch, James E. and Vitor Trindade, 2002, "Ethnic Chinese Networks in International Trade," Review of Economics and Statistics, 84(1), February, 116-130.

Rauch, James E. and Joel Watson, 2002, “Entrepreneurship and International Trade,” NBER Working Paper no. 8708. 
Redding, Stephen and Anthony Venables, 2000, "Economic Geography and International Inequality," CEPR Discussion paper no. 2568.

Sung, Yun-Wing, 1991, The China-Hong Kong Connection, Cambridge, UK: Cambridge University Press.

Train, Kenneth, 1986, Qualitative Choice Analysis. Cambridge: MIT Press.

Young, Alwyn, 1999, “Transport, Processing and Information: Value Added and the Circuitous Movement of Goods," May, Univ. of Chicago, manuscript.

Wan, Henry Y, Jr., and Jason Weisman, 1999, "Hong Kong: The Fragile Economy of Middlemen." Review of International Economics 7(3): 410-530.

Whinston, Michael D., 2000, "On the Transaction Cost Determinants of Vertical Integration," Northwestern University, manuscript. 
Table 1: Direct Exports and Re-exports of Chinese Goods (Percent)

\begin{tabular}{ccccccc}
\hline & Total & Re-Export & \multicolumn{3}{c}{ Re-Export } & \multicolumn{3}{c}{ Outward Processing Share of China: } \\
Year: & $\begin{array}{c}\text { China Exports } \\
\text { (billions US\$) }\end{array}$ & $\begin{array}{c}\text { Share of Total } \\
\text { China Exports }\end{array}$ & $\begin{array}{c}\text { Share of China } \\
\text { Processing } \\
\text { Direct } \\
\text { Exports }\end{array}$ & $\begin{array}{c}\text { Re-exports to } \\
\text { Exports }\end{array}$ & $\begin{array}{c}\text { Total } \\
\text { Hong Kong }\end{array}$ & Exports \\
\hline \hline & $(1)$ & $(2)$ & $(3)$ & $(4)$ & $(5)$ & $(6)$ \\
88 & 38.7 & 43.1 & 66.7 & 12.8 & 49.7 & 32.1 \\
89 & 46.3 & 51.5 & 72.7 & 19.7 & 56.9 & 40.3 \\
90 & 55.4 & 55.2 & 74.4 & 21.9 & 58.5 & 43.4 \\
91 & 67.8 & 59.1 & 77.2 & 24.9 & 61.5 & 47.1 \\
92 & 84.7 & 60.1 & 79.2 & 24.8 & 63.1 & 47.9 \\
93 & 98.0 & 61.3 & 83.4 & 24.4 & 67.2 & 49.4 \\
94 & 120.2 & 57.7 & 75.1 & 27.4 & 62.1 & 47.7 \\
95 & 151.6 & 53.3 & 70.0 & 32.7 & 65.8 & 50.1 \\
96 & 161.0 & 49.8 & 69.7 & 38.1 & 76.0 & 54.3 \\
97 & 181.3 & 46.9 & 62.2 & 39.6 & 69.9 & 52.7 \\
98 & 177.7 & 45.4 & 61.3 & 40.7 & 73.8 & 54.7 \\
\hline
\end{tabular}

Notes: Column (1) shows total China exports (direct exports plus re-exports through Hong Kong) in billions of current U.S. dollars; column (2) shows Chinese re-exports through Hong Kong as a share of total Chinese exports; column (3) shows Chinese re-exports through Hong Kong of outward processing goods as a share of total Chinese outward processing exports; columns (3)-(5) shows the share of exports related to outward processing in direct Chinese exports to countries other than Hong Kong, Chinese re-exports to Hong Kong, and total Chinese exports. 
Table 2: Direct Exports and Re-exports of Chinese Goods, by One-digit SITC Industry (Percent)

\begin{tabular}{|c|c|c|c|c|c|c|}
\hline \multirow{2}{*}{\multicolumn{2}{|c|}{ SITC Industry: }} & \multirow{3}{*}{$\begin{array}{c}\text { Industry } \\
\text { Share of } \\
\text { Total } \\
\text { Exports } \\
(1)\end{array}$} & \multirow{3}{*}{$\begin{array}{l}\text { Re-Export } \\
\text { Share of } \\
\text { Industry } \\
\text { Exports } \\
(2)\end{array}$} & \multirow{3}{*}{$\begin{array}{c}\text { Re-Export } \\
\text { Share of } \\
\text { Industry } \\
\text { Processing } \\
\text { Exports } \\
(3)\end{array}$} & \multicolumn{2}{|c|}{$\begin{array}{l}\text { Outward Processing } \\
\text { Share of Industry: }\end{array}$} \\
\hline & & & & & Direct & Exports to \\
\hline & & & & & (4) & (15) \\
\hline 0 & $\begin{array}{l}\text { Food and Live } \\
\text { Animals }\end{array}$ & 6.5 & 14.2 & 19.8 & 8.9 & 16.0 \\
\hline 1 & $\begin{array}{l}\text { Beverages and } \\
\text { Tobacco }\end{array}$ & 0.4 & 35.1 & 51.3 & 6.7 & 17.0 \\
\hline 2 & Crude Materials & 3.9 & 22.0 & 51.8 & 2.8 & 11.6 \\
\hline 3 & Mineral Fuels & 4.8 & 0.6 & 3.3 & 3.9 & 15.8 \\
\hline 4 & $\begin{array}{l}\text { Animal and } \\
\text { Vegetable Oils }\end{array}$ & 0.1 & 17.1 & 0.0 & 15.1 & 72.5 \\
\hline 5 & Chemical Products & 4.7 & 21.9 & 30.5 & 12.9 & 27.6 \\
\hline 6 & $\begin{array}{l}\text { Manufactured Goods } \\
\text { Classified by Material }\end{array}$ & 17.8 & 41.6 & 44.4 & 28.0 & 42.1 \\
\hline 7 & $\begin{array}{l}\text { Machinery and } \\
\text { Transport Equip. }\end{array}$ & 17.2 & 69.5 & 75.4 & 44.7 & 84.4 \\
\hline 8 & $\begin{array}{l}\text { Misc. Manufactured } \\
\text { Articles }\end{array}$ & 43.4 & 70.1 & 73.6 & 43.9 & 71.4 \\
\hline
\end{tabular}

Notes: Column (1) shows each one-digit SITC industry's share of total Chinese exports ; column (2) shows the share of re-exports in each industry's total exports; column (3) shows re-exports through Hong Kong of outward processing goods as a share of industry outward processing exports; and columns (4)-(5) shows the share of exports related to outward processing in direct industry exports to countries other than Hong Kong, and industry re-exports to Hong Kong. All figures are averages over the 1988-1998 period 
Table 3: Direct Exports and Re-Exports of Chinese Goods by Region (Percent)

\begin{tabular}{lccc}
\hline Region & $\begin{array}{c}\text { Region } \\
\text { Share of } \\
\text { Direct Exports }\end{array}$ & $\begin{array}{c}\text { Region } \\
\text { Share of } \\
\text { Re-Exports }\end{array}$ & $\begin{array}{c}\text { Re-Export } \\
\text { Share of } \\
\text { Total Exports }\end{array}$ \\
\hline \hline & $(1)$ & $(2)$ & $(3)$ \\
Africa & 3.2 & 2.6 & 49.9 \\
East Asia & 36.8 & 18.0 & 35.6 \\
Eastern Europe & 4.2 & 0.9 & 24.8 \\
Latin America & 2.5 & 4.2 & 65.0 \\
Middle East & 4.0 & 2.6 & 42.8 \\
North America & 16.7 & 37.3 & 71.4 \\
Oceania & 1.7 & 2.4 & 61.2 \\
South Asia & 2.7 & 1.0 & 30.6 \\
Southeast Asia & 11.2 & 6.0 & 37.8 \\
Western Europe & 16.9 & 24.9 & 62.1 \\
\hline
\end{tabular}

Notes: This table shows each region's share of Chinese direct exports in column (1) and of total re-exports of Chinese goods by Hong Kong in column (2). Column (3) shows the share of reexports in Chinese exports to each region. All figures are averages over the period 1988-1998. 
Table 4: Gravity Equation at Aggregate Level, 1995

\section{Direct China Trade}

Hong Kong Re-exports

\section{Using Arc Distance}

Arc Distance

$-1.08$

1.56

$(-5.73)$

(6.39)

Observations

1920

4154

R-squared

0.62

0.84

\section{Using Internal-External Distance}

Internal Distance

$-0.59$

External Distance

$-0.86$

$-0.23$

Observations

1920

R-squared

0.61

4154

0.85

Notes: This table shows regressions results for the specification in equation (19). The dependent variable is the log ratio of outward processing exports by Chinese province, industry, and destination country to total outward processing exports by industry and destination country (regressions are run separately for each year). The independent variables are log distance, indicator variables for the destination country, and indicator variables for the Chinese province. The regressions are run separately for two outsourcing modes, direct exports from China and re-exports of Chinese goods through Hong Kong. T-statistics are in parentheses. 
Table 5: Gravity Equation for SITC Industries, 1995

\begin{tabular}{|c|c|c|c|c|c|c|c|c|}
\hline & $\begin{array}{r}\text { Dir } \\
\text { Internal } \\
\text { Distance }\end{array}$ & $\begin{array}{l}\text { ect China } \\
\text { External } \\
\text { Distance }\end{array}$ & $\begin{array}{l}\text { Trade } \\
\text { Obs. }\end{array}$ & $\mathrm{R}^{2}$ & \begin{tabular}{|c} 
Hong \\
Internal \\
Distance \\
\end{tabular} & $\begin{array}{l}\text { Kong Re } \\
\text { External } \\
\text { Distance }\end{array}$ & $\begin{array}{l}\text { Expor } \\
\text { Obs. }\end{array}$ & $\begin{array}{l}\text { ts } \\
\mathrm{R}^{2}\end{array}$ \\
\hline $\begin{array}{l}\text { Food and } \\
\text { Live Animals }\end{array}$ & $\begin{array}{c}-0.44 \\
(-1.82)\end{array}$ & $\begin{array}{l}-1.59 \\
(-3.25)\end{array}$ & 338 & 0.65 & $\begin{array}{l}-0.45 \\
(-7.04)\end{array}$ & $\begin{array}{l}-0.04 \\
(-0.17)\end{array}$ & 1516 & 0.77 \\
\hline $\begin{array}{l}\text { Beverages and } \\
\text { Tobacco }\end{array}$ & $\begin{array}{l}-0.74 \\
(-2.57)\end{array}$ & $\begin{array}{c}-0.1 \\
(-0.13)\end{array}$ & 83 & 0.73 & $\begin{array}{c}0.90 \\
(9.66)\end{array}$ & $\begin{array}{l}-0.33 \\
(-0.86)\end{array}$ & 362 & 0.70 \\
\hline $\begin{array}{l}\text { Crude } \\
\text { Materials }\end{array}$ & $\begin{array}{l}-0.07 \\
(-0.27)\end{array}$ & $\begin{array}{l}-1.01 \\
(-1.62)\end{array}$ & 172 & 0.62 & $\begin{array}{l}0.23 \\
(1.8)\end{array}$ & $\begin{array}{c}0.4 \\
(1.22)\end{array}$ & 654 & 0.69 \\
\hline Mineral Fuels & $\begin{array}{c}0.64 \\
(1.15)\end{array}$ & $\begin{array}{l}-1.32 \\
(-0.45)\end{array}$ & 76 & 0.72 & $\begin{array}{c}0.19 \\
(9.19)\end{array}$ & $\begin{array}{l}-0.07 \\
(-0.74)\end{array}$ & 220 & 0.97 \\
\hline $\begin{array}{l}\text { Animal and } \\
\text { Vegetable Oils }^{\mathrm{a}}\end{array}$ & - & - & - & - & $\begin{array}{c}-0.09 \\
(-0.38)\end{array}$ & $\begin{array}{c}1.02 \\
(1.34)\end{array}$ & 80 & 0.89 \\
\hline $\begin{array}{l}\text { Chemical } \\
\text { Products }\end{array}$ & $\begin{array}{c}-0.17 \\
(-1.49)\end{array}$ & $\begin{array}{l}-1.37 \\
(-3.63)\end{array}$ & 624 & 0.62 & $\begin{array}{c}-0.46 \\
(-13.01)\end{array}$ & $\begin{array}{c}0.25 \\
(1.34)\end{array}$ & 2507 & 0.76 \\
\hline $\begin{array}{l}\text { Manufactured Goods } \\
\text { Classified by Material }\end{array}$ & $\begin{array}{c}-0.34 \\
(-2.76)\end{array}$ & $\begin{array}{c}-0.95 \\
(-3.79)\end{array}$ & 1365 & 0.50 & $\begin{array}{c}-0.58 \\
(-21.54)\end{array}$ & $\begin{array}{l}0.11 \\
(0.8)\end{array}$ & 3577 & 0.72 \\
\hline $\begin{array}{l}\text { Machinery and } \\
\text { Transport Equip. }\end{array}$ & $\begin{array}{l}-0.40 \\
(-3.79)\end{array}$ & $\begin{array}{c}-0.86 \\
(-2.21)\end{array}$ & 1026 & 0.51 & $\begin{array}{c}-0.65 \\
(-28.75)\end{array}$ & $\begin{array}{c}0.06 \\
(0.42)\end{array}$ & 3474 & 0.79 \\
\hline $\begin{array}{l}\text { Misc. Manufactured } \\
\text { Articles }\end{array}$ & $\begin{array}{l}-0.51 \\
(-4.94)\end{array}$ & $\begin{array}{c}-1.86 \\
(-5.94)\end{array}$ & 1296 & 0.64 & $\begin{array}{c}-0.86 \\
(-56.4)\end{array}$ & $\begin{array}{c}0.02 \\
(0.18)\end{array}$ & 3962 & 0.91 \\
\hline
\end{tabular}

Notes:

a. There are insufficient observations on direct China trade for Animal and Vegetable Oils.

The regression results in this table reproduce the results in Table 4 separately for each one-digit SITC industry. See notes to that table for further details. T-statistics are in parentheses. 
Table 6: Second-Stage Estimation at Aggregate Level

\begin{tabular}{|c|c|c|c|}
\hline $\begin{array}{l}\text { Hong Kong } \\
\text { Indicator }\end{array}$ & $\begin{array}{c}\text { China } \\
\text { Indicator }\end{array}$ & Obs. & $\mathrm{R}^{2}$ \\
\hline \multicolumn{4}{|c|}{ Using Arc Distance } \\
\hline $\begin{array}{c}-0.16 \\
(-5.38)\end{array}$ & $\begin{array}{c}0.19 \\
(6.06)\end{array}$ & 1582 & 0.04 \\
\hline \multicolumn{4}{|c|}{ Using Internal-External Distance } \\
\hline $\begin{array}{l}-0.28 \\
(-5.08)\end{array}$ & $\begin{array}{c}0.17 \\
(5.46)\end{array}$ & 1582 & 0.04 \\
\hline
\end{tabular}

Notes: This table reports regression results for equation (20), using data over 1988-1998. The dependent variable is the log ratio of direct China outward processing exports to Hong-Kong reexports of outward processed goods from China by industry and destination country (regressions are run separately for each year). The independent variables are the coefficients on the indicator variables for destination country from the regressions in column (1) and column (2) in Table 4. Standard errors are corrected by using bootstrap techniques and t-statistics are in parentheses. 
Table 7: Second Stage Estimation for SITC Industries

\begin{tabular}{|c|c|c|c|c|}
\hline & $\begin{array}{l}\text { Hong Kong } \\
\text { Indicator }\end{array}$ & $\begin{array}{c}\text { China } \\
\text { Indicator }\end{array}$ & Obs. & $\mathrm{R}^{2}$ \\
\hline $\begin{array}{l}\text { Food and } \\
\text { Live Animals }\end{array}$ & $\begin{array}{c}-0.41 \\
(-3.40)\end{array}$ & $\begin{array}{c}0.44 \\
(8.80)\end{array}$ & 689 & 0.13 \\
\hline $\begin{array}{l}\text { Beverages and } \\
\text { Tobacco }\end{array}$ & $\begin{array}{c}-0.44 \\
(-3.63)\end{array}$ & $\begin{array}{c}0.07 \\
(0.90)\end{array}$ & 220 & 0.07 \\
\hline $\begin{array}{l}\text { Crude } \\
\text { Materials }\end{array}$ & $\begin{array}{l}-0.27 \\
(-2.83)\end{array}$ & $\begin{array}{c}0.29 \\
(6.68)\end{array}$ & 385 & 0.15 \\
\hline Mineral Fuels & $\begin{array}{c}-0.16 \\
(-0.43)\end{array}$ & $\begin{array}{c}0.22 \\
(3.52)\end{array}$ & 129 & 0.15 \\
\hline $\begin{array}{l}\text { Chemical } \\
\text { Products }\end{array}$ & $\begin{array}{c}-0.52 \\
(-7.80)\end{array}$ & $\begin{array}{c}0.42 \\
(12.32)\end{array}$ & 1080 & 0.22 \\
\hline $\begin{array}{l}\text { Manufactured Goods } \\
\text { Classified by Material }^{\text {a }}\end{array}$ & $\begin{array}{c}0.16 \\
(2.77)\end{array}$ & $\begin{array}{c}-0.03 \\
(-0.74)\end{array}$ & 1337 & 0.08 \\
\hline $\begin{array}{l}\text { Machinery and } \\
\text { Transport Equip. }\end{array}$ & $\begin{array}{l}-0.19 \\
(-4.31)\end{array}$ & $\begin{array}{l}-0.005 \\
(-0.16)\end{array}$ & 1255 & 0.07 \\
\hline $\begin{array}{l}\text { Misc. Manufactured } \\
\text { Articles }\end{array}$ & $\begin{array}{c}0.05 \\
(0.98)\end{array}$ & $\begin{array}{c}0.30 \\
(11.99)\end{array}$ & 1359 & 0.15 \\
\hline
\end{tabular}

Notes:

a The estimation results using arc distance in the gravity equation are:

$\begin{array}{lcccc} & \text { Hong Kong } & \text { China } & & \\ & \text { Indicator } & \text { Indicator } & \text { Obs. } & \mathrm{R}^{2} \\ \text { Manufactured Goods } & -0.23 & 0.12 & 1337 & 0.08 \\ \text { Classified by Material } & (-8.61) & (3.45) & & \end{array}$

The regression results in this table reproduce the results in Table 6 separately for each one-digit SITC industry. Standard errors are corrected by using bootstrap techniques and t-statistics are in parentheses. See notes to that table for further details. 
Table 8: Welfare Gain from Hong Kong Re-exports of Processing Trade, by SITC Industry

\begin{tabular}{ccccccc}
\hline Year & $\begin{array}{c}\text { Markups in } \\
\text { Hong Kong }\end{array}$ & $\begin{array}{c}\text { Share of } \\
\text { China } \\
\text { Processing } \\
\text { Exports }(\%)\end{array}$ & $\begin{array}{c}\text { Implied } \\
\text { Value of } \\
\left(1-\rho_{1}\right)\end{array}$ & $\begin{array}{c}\text { Implied } \\
\text { Value of } \\
\left(1-\rho_{0}\right)\end{array}$ & $\begin{array}{c}\text { Re-Export } \\
\text { Share of } \\
\text { Chinese } \\
\text { Processing } \\
\text { Exports }(\%)\end{array}$ & $\begin{array}{c}\text { Welfare Gain } \\
(\% \text { of } \\
\text { Processing } \\
\text { Exports })\end{array}$ \\
\hline \hline & $(1)$ & $(2)$ & $(3)$ & $(4)$ & $(5)$ & $(6)$ \\
88 & 0.24 & na & na & na & 66.7 & na \\
89 & 0.26 & 12.2 & 0.043 & 0.152 & 72.7 & 11.0 \\
90 & 0.25 & 18.3 & 0.062 & 0.222 & 74.4 & 16.5 \\
91 & 0.27 & 16.3 & 0.060 & 0.216 & 77.2 & 16.6 \\
92 & 0.23 & 14.7 & 0.045 & 0.159 & 79.2 & 12.6 \\
93 & 0.17 & 15.2 & 0.030 & 0.109 & 83.4 & 9.1 \\
94 & 0.25 & 16.1 & 0.054 & 0.191 & 75.1 & 14.4 \\
95 & 0.25 & 22.2 & 0.072 & 0.258 & 70 & 18.0 \\
96 & 0.23 & 27.2 & 0.079 & 0.282 & 69.7 & 19.7 \\
97 & 0.12 & 31.2 & 0.041 & 0.145 & 62.2 & 9.0 \\
98 & 0.25 & 33.7 & 0.111 & 0.397 & 61.3 & 24.3 \\
Average & 0.22 & 23.0 & 0.065 & 0.232 & 70.1 & 16.2 \\
\hline
\end{tabular}

\section{Notes:}

Columns (1) is computed from Hong Kong trade data, and is denoted by $\bar{\pi}_{1}$ in the text. Columns (2) is computed from Chinese processing trade data, and is denoted by $\alpha_{1}$ in the text. Column (3) equals $\hat{\alpha}_{1} /\left[\left(1 / \bar{\pi}_{1}\right)-1\right]$. Column (4) equals $\left(1-\hat{\rho}_{1}\right) / 0.28$, where 0.28 is the absolute coefficient of the Hong Kong indicator variable for processing trade in Table 6. Column (5) is obtained from Table 1, and column (6) equals columns (4) times (5). 
Table 9: Welfare Gain from Hong Kong Re-exports of Processing Trade, by SITC Industry

\begin{tabular}{|c|c|c|c|c|c|c|}
\hline SITC & Industry & $\begin{array}{l}\text { Industry } \\
\text { Markups in } \\
\text { Hong Kong }\end{array}$ & $\begin{array}{l}\text { Implied } \\
\text { Value of } \\
\left(1-\rho_{1}\right)\end{array}$ & $\begin{array}{l}\text { Implied } \\
\text { Value of } \\
\left(1-\rho_{0}\right)\end{array}$ & $\begin{array}{l}\text { Re-export } \\
\text { Share of } \\
\text { Industry } \\
\text { Processing } \\
\text { Exports } \\
\end{array}$ & $\begin{array}{l}\text { Welfare } \\
\text { Gain } \\
\text { (\% of } \\
\text { Processing } \\
\text { Exports) } \\
\end{array}$ \\
\hline & & (1) & (2) & (3) & (4) & (5) \\
\hline 0 & Food and Live Animals & 0.11 & 0.028 & 0.069 & 19.8 & 1.4 \\
\hline 1 & Beverages and Tobacco & 0.05 & 0.013 & 0.030 & 51.3 & 1.5 \\
\hline 2 & Crude Materials & 0.27 & 0.084 & 0.310 & 51.8 & 16.1 \\
\hline 3 & Mineral Fuels & 0.09 & 0.023 & 0.142 & 3.3 & 0.5 \\
\hline 4 & $\begin{array}{l}\text { Animal and Vegetable } \\
\text { Oils }\end{array}$ & 0.07 & 0.017 & na & 0.0 & na \\
\hline 5 & Chemical Products & 0.05 & 0.011 & 0.022 & 30.5 & 0.7 \\
\hline 6 & $\begin{array}{l}\text { Manufactured Goods } \\
\text { Classified by Material }\end{array}$ & 0.18 & 0.051 & 0.221 & 44.4 & 9.8 \\
\hline 7 & $\begin{array}{l}\text { Machinery and } \\
\text { Transport Equip. }\end{array}$ & 0.19 & 0.053 & 0.277 & 75.4 & 20.9 \\
\hline \multirow[t]{2}{*}{8} & $\begin{array}{l}\text { Misc. Manufactured } \\
\text { Articles }\end{array}$ & 0.24 & 0.072 & na & 73.6 & na \\
\hline & All Industries & 0.22 & 0.065 & 0.232 & 70.1 & 16.2 \\
\hline
\end{tabular}

\section{Notes:}

Columns (1) is computed from Hong Kong trade data, and is denoted by $\bar{\pi}_{1}$ in the text. Column (2) equals $0.23 /\left[\left(1 / \bar{\pi}_{1}\right)-1\right]$. Column (3) equals $\left(1-\hat{\rho}_{1}\right)$ divided by the coefficient of the Hong Kong indicator variable for processing trade in Table 7. Column (4) is obtained from Table 2, and column (5) equals columns (3) times (4). 


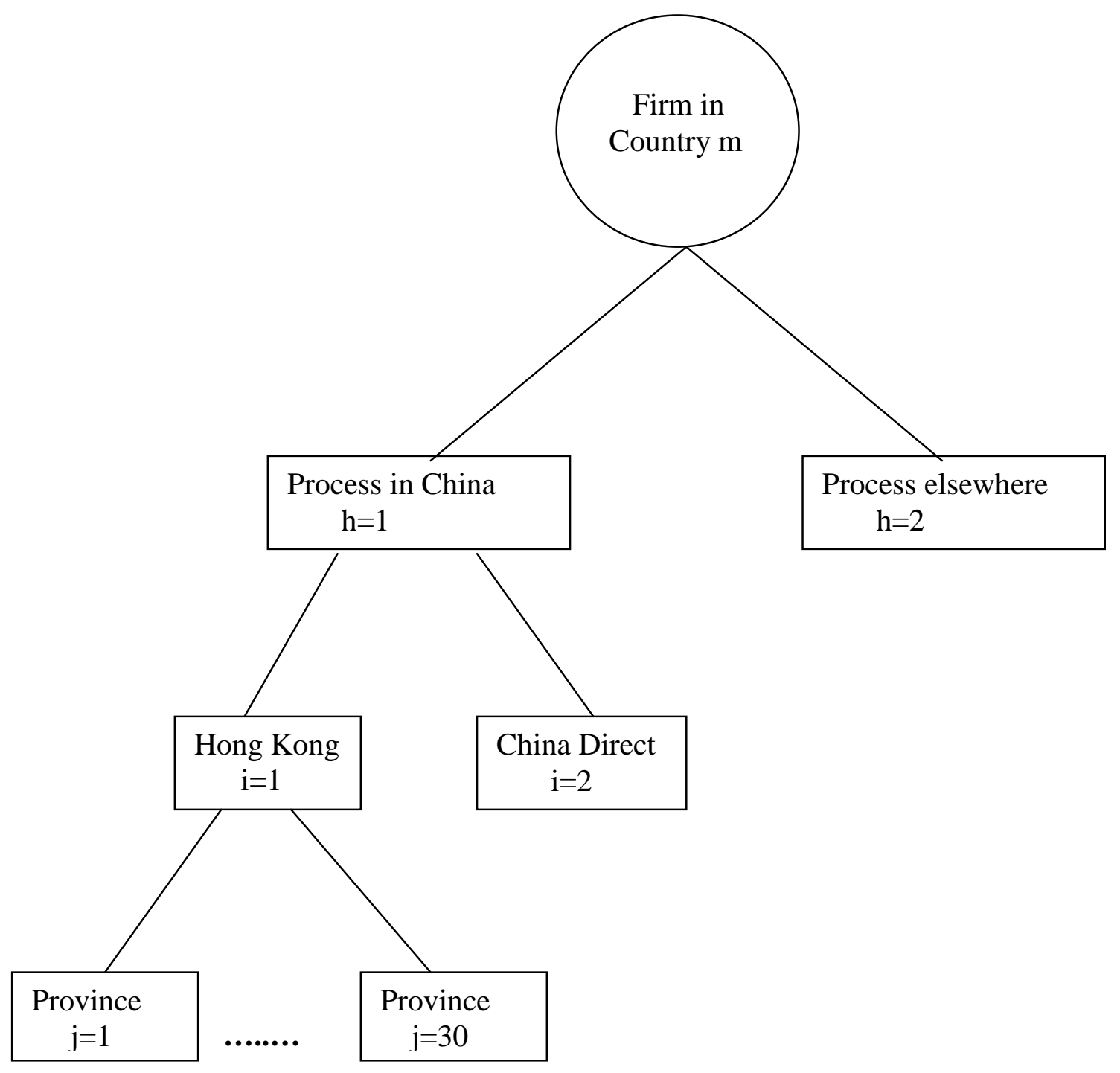

Figure 1: Decision Tree for Firm Outsourcing 